\title{
Increase of Adipose Tissue Lipoprotein Lipase Activity with Weight Loss
}

\author{
Robert S. SChWARTZ and John D. BRUNZell, Division of Metabolism and \\ Endocrinology, Department of Medicine, University of Washington, \\ Seattle, Washington 98195
}

\begin{abstract}
A B S T R A C T Obese subjects have elevated adipose tissue lipoprotein lipase activity per fat cell when compared with lean control subjects. This enzyme, which is rate limiting for the uptake and storage of lipoprotein triglyceride in adipose tissue, has been shown to be further elevated in a group of previously obese subjects who had been weight stable at a reduced weight for 4$28 \mathrm{mo}$. In the present prospective study of eight obese subjects, adipose tissue lipoprotein lipase activity was demonstrated to increase after weight stabilization at a reduced weight ( $9.33 \mathrm{mU} / 10^{6}$ cells) when compared with basal obese levels $\left(2.17 \mathrm{mU} / 10^{6}\right.$ cells $)$. In three subjects who lost weight and subsequently regained their lost weight, the enzyme activity increased after weight loss and then returned toward the original basal level with weight gain. One subject who maintained his weight loss for 10 mo continued to have an elevated level of enzyme activity. Because adipose tissue lipoprotein lipase activity does not "normalize" after weight loss, we hypothesize that this enzyme may play a counterregulatory role in resisting deviation from a "set point" for fat mass or fat cell size and thereby predispose to reattainment of the original obese state.
\end{abstract}

\section{INTRODUCTION}

Obesity is a major public health problem affecting a great number of adults in the United States (1). Treatment of this disorder is considered by most physicians and patients to be discouraging; $<5 \%$ of subjects losing a significant amount of weight by any technique $(2,3)$ other than surgery are able to keep it off for 3-5 yr. Because of this impressive tendency for obese patients to regain lost weight and for thin individuals to lose weight they have gained by enforced overeating (4), a specific

Dr. Schwartz is the recipient of National Institutes of Health fellowship IF $32 \mathrm{HL} 18687$. His present address is University of Vermont, Department of Medicine, Metabolic Unit, Burlington, Vermont 05405.

Received for publication 21 June 1980 and in revised form 30 December 1980. "set point" for fat mass or fat cell size has been postulated $(4,5)$. Deviation either above or below the set point might stimulate counterregulatory mechanisms to come into play, driving the patient back toward this set point.

Obesity is known to be accompanied by many metabolic abnormalities: insulin resistance with elevations in basal and glucose-stimulated insulin concentrations $(6,7)$; increased fat cell volume $(8)$; increased glucose incorporation into triglyceride by adipose tissue $(9,10)$; enhanced basal and stimulated lipolysis (11); and elevated fasting triglyceride concentrations (7). All of these abnormalities are reversible, however, and normalize with weight loss $(6-11)$. For this reason, it is likely that they are a consequence of the obesity, not a cause.

Adipose tissue lipoprotein lipase (AT-LPL) ${ }^{1}$ is the rate-limiting enzyme responsible for the uptake and storage of lipoprotein triglyceride by the adipocyte (12). This enzyme is made in the cytoplasm of the adipocyte and transported to the capillary endothelium, where it hydrolyzes fatty acids from the triglyceride circulating in the core of very low density lipoproteins and chylomicrons $(13,14)$. The released fatty acids are then taken up by the adipocyte and reesterified to triglyceride, which is stored in the lipid droplet (12). The unique position of the enzyme AT-LPL with regard to fat storage suggests that it is a candidate for a role in the development of human obesity and/or the maintenance of the obese state.

AT-LPL activity per cell has been demonstrated to be elevated in obesity and is positively correlated with fat cell size as well as relative weight by actuarial table (percent of ideal body weight [\%IBW]) $(15,16)$. If this elevation in AT-LPL, like most other metabolic abnormalities associated with obesity, is a consequence of the obese state, its activity would decline with weight

\footnotetext{
${ }^{1}$ Abbreviations used in this paper: AT-LPL, adipose tissue lipoprotein lipase; HDL, high density lipoprotein; \%IBW, percent of ideal body weight; VLDL-TG, very low density lipoprotein triglyceride.
} 
loss. If, however, the AT-LPL activity remains elevated or increases further with weight loss, this enzyme might be playing a causal role in the maintenance of obesity.

Other studies (17) have revealed that previously obese subjects, who by careful chronic dieting were able to maintain a stable reduced weight for 4-28 mo, had AT-LPL activity threefold greater than predicted for their degree of obesity (\%IBW) or their fat cell size. This retrospective analysis supports the hypothesis that AT-LPL activity was increased in these stable, reduced subjects as a counterregulatory attempt to increase triglyceride storage and return fat cell size, and thus fat mass, toward the original obese set point. Alternatively, those unusual individuals who were able to maintain their weight loss might have been a unique subgroup that always had greatly elevated AT-LPL activity. To evaluate these possibilities, prospective weight loss studies were performed, and the AT-LPL response was determined.

\section{METHODS}

Eight obese $(175 \pm 68 \%$ IBW $)$ but otherwise healthy male volunteers were admitted to the University of Washington Clinical Research Center for weight loss (Table I). Seven volunteers were moderately obese, with onset of obesity after adolescence. The eighth had life-long massive obesity. None of them had known endocrinological causes of obesity and all had normal fasting plasma glucose levels. They were placed on a weight maintaining "basal" liquid formula diet comprised of $45 \%$ carbohydrate, $40 \%$ fat and $15 \%$ protein. The calorie intake was determined by the relationship between calories per kilogram and relative weight as previously reported (18). The last $4 \mathrm{~d}$ of the 1 -wk weight stabilization period showed a rate of weight change of $<50 \mathrm{~g} / \mathrm{d}$ in each subject. After this weight stabilization period, a baseline adipose tissue biopsy for lipoprotein lipase activity was obtained at $8 \mathrm{~A} . \mathrm{M}$. after an overnight fast. The subjects then began a $600-\mathrm{kcal}$ (50\% protein, $50 \%$ carbohydrate) liquid formula weight reduction diet, which was continued until the subject felt he could no longer lose weight and wished to discontinue the diet. Each was then restabilized for $1 \mathrm{wk}$ at the reduced weight on the original "basal" formula diet, and the adipose tissue biopsy was repeated. AT-LPL also was measured in four of the subjects at the end of a 1- to 2-wk period of weight stabilization at the midpoint of the weight loss protocol.

All subjects were given multiple vitamins and a stool softener throughout the study but took no other drugs. Two of the eight subjects (Nos. 2 and 4) were cigarette smokers, and except for the mornings before studies, when tobacco was withheld, they continued their usual smoking habit throughout the study.

AT-LPL was measured as the heparin-releasable enzyme as previously described (16). Adipose tissue specimens were

TABLE I

Effect of Weight Reduction

\begin{tabular}{|c|c|c|c|c|c|c|c|c|}
\hline Patient & Age & Weight & IBW & Fat cell size & AT-LPL & $\begin{array}{l}\text { VLDL- } \\
\text { TG }\end{array}$ & $\begin{array}{c}\text { HDL } \\
\text { cholesterol }\end{array}$ & $\begin{array}{c}\text { LDL } \\
\text { cholesterol }\end{array}$ \\
\hline & & $k g$ & $\%$ & $\mu g$ TG/cell & $m U / 10^{6}$ cells & $m g / d l$ & $m g / d l$ & $\mathrm{mg} / \mathrm{dl}$ \\
\hline 1 Obese & 44 & 149 & 207 & 0.794 & 4.13 & 351 & 37 & 87 \\
\hline Reduced & & 138 & 192 & 0.673 & 11.81 & 204 & 33 & 93 \\
\hline 2 Obese & 34 & 103 & 148 & 0.576 & 1.43 & 204 & 28 & 115 \\
\hline Reduced & & 80 & 115 & 0.573 & 4.33 & 115 & 61 & 103 \\
\hline 3 Obese & 27 & 92 & 149 & 0.606 & 1.62 & 91 & 32 & 137 \\
\hline Reduced & & 83 & 134 & 0.576 & 12.16 & 173 & 33 & 145 \\
\hline 4 Obese & 34 & 80 & 131 & 0.705 & 2.72 & 136 & 24 & 124 \\
\hline Reduced & & 74 & 120 & 0.613 & 3.13 & 69 & 46 & 114 \\
\hline 5 Obese & 31 & 97 & 144 & 0.619 & 0.88 & 188 & 28 & 85 \\
\hline Reduced & & 81 & 119 & 0.541 & 0.81 & 126 & 35 & 85 \\
\hline 6 Obese & 24 & 99 & 143 & 0.770 & 2.01 & 171 & 31 & 153 \\
\hline Reduced & & 83 & 120 & 0.678 & 8.42 & 126 & 31 & 99 \\
\hline 7 Obese & 25 & 95 & 148 & 0.484 & 1.09 & 135 & 33 & 71 \\
\hline Reduced & & 84 & 130 & 0.571 & 29.03 & 75 & 37 & 108 \\
\hline 8 Obese & 39 & 252 & 333 & 0.743 & 3.49 & 50 & 28 & 123 \\
\hline Reduced & & 213 & 285 & 0.560 & 4.97 & 31 & 41 & 99 \\
\hline \multirow{3}{*}{$\begin{array}{c}\text { Mean } \pm S D \\
\text { Obese } \\
\text { Reduced }\end{array}$} & & & & & & & & \\
\hline & $32 \pm 7$ & $121 \pm 56$ & $175 \pm 68$ & $0.662 \pm 0.108$ & $2.17 \pm 1.17$ & $166 \pm 90$ & $30 \pm 4$ & $112 \pm 28$ \\
\hline & & $105 \pm 48$ & $152 \pm 60$ & $0.598 \pm 0.052$ & $9.33 \pm 8.93$ & $115 \pm 56$ & $40 \pm 10$ & $106 \pm 18$ \\
\hline \multicolumn{2}{|l|}{$P$ value } & 0.01 & 0.01 & 0.05 & 0.03 & 0.09 & 0.05 & $>0.3$ \\
\hline
\end{tabular}


obtained by suction needle biopsy of subcutaneous tissue in the area of the buttock. The tissue pieces were rinsed with $100 \mathrm{ml}$ of cold Krebs-Ringer phosphate buffer ( $\mathrm{pH} 7.4$ ) dried on lipid-free sharkskin filter paper and cut into pieces of uniform size. Approximately $45 \mathrm{mg}$ of tissue was incubated in duplicate flasks for $45 \mathrm{~min}$ at $37^{\circ} \mathrm{C}$ in $2.5 \mathrm{ml}$ of Krebs-Ringer buffer with heparin $(2 \mathrm{U} / \mathrm{ml})$. At the end of the incubation period, two $1-\mathrm{ml}$ samples of heparin-eluted enzyme were taken from each flask for assay.

The substrate for the AT-LPL assay was prepared using 200 $\mu \mathrm{l}$ of unlabeled triolein $\left(25 \mathrm{mg} / \mathrm{ml}\right.$ in benzene); $100 \mu \mathrm{l}$ of $\left[1-{ }^{14} \mathrm{C}\right]-$ triolein $(2 \mu \mathrm{Ci} / \mathrm{ml}$ in benzene); and $20 \mu \mathrm{l}$ of purified egg lecithin $(12 \mathrm{mg} / \mathrm{ml}$ in $1: 1$ chloroform:methanol). These were evaporated with nitrogen and emulsified in $2 \mathrm{ml}$ of a mixture of $10 \%$ fatty acid-free bovine serum albumin ( $\mathrm{pH} 8.0$ ), pooled human serum as a source of enzyme activator, $2 \mathrm{M}$ Tris- $\mathrm{HCl}$ buffer ( $\mathrm{pH} 8.2$ at $37^{\circ} \mathrm{C}$ ), and distilled water (vol/vol 4:1.5:5:9.5) for a total of 3 min with a Branson 125 Sonifier (Branson Sonic Power Co., Danbury, Conn.). The substrate was kept cool on ice during and after sonification for a minimum of $30 \mathrm{~min}$ before use.

The l-ml aliquot of the medium containing the heparineluted enzyme activity was added to $0.2 \mathrm{ml}$ of substrate and incubated at $37^{\circ} \mathrm{C}$ in a metabolic shaker. The reaction was stopped at $45 \mathrm{~min}$ by adding Dole's reagent, and free fatty acids were extracted and specific activity was determined. AT-LPL activity is expressed as milliunits per million fat cells with one milliunit equal to a nanoequivalent of free fatty acids released per minute.

Fat cell diameter was determined from formalin-fixed frozen sections of fat by the method of Sjöstrom et al. (19). Fat cell volume (micrograms of triglyceride per cell) was calculated by the equation of Goldrick (20), and fat cell number was determined by dividing the tissue weight by the mean fat cell volume. To reduce assay variability, plasma activator pool, triolein substrate, and albumin lots were not changed during this study. The precision of replicate analysis was $5.9 \%$ within an assay and $8.9 \%$ between assays in subjects at their usual weight. The coefficient of variation between assays in a single, weight-stable, reduced individual biopsied seven times over a period of 25 mo was $13.6 \%$ ( $n=7,8.44 \pm 1.15 \mathrm{mU} / 10^{6}$ cells).

Plasma lipoprotein was analysed in each subject in the fasting weight-stable state before and after weight reduction by the plasma ultracentrifugation technique used in the Lipid Research Clinics Program (21). \%IBW was calculated from the Metropolitan Life Insurance Co. (New York) tables, using the midpoint of the range for medium build. The Wilcoxon signed rank test for paired values was used to evaluate differences in subjects before and after weight loss. Results are reported as mean \pm SD.

\section{RESULTS}

The mean \%IBW for the eight patients in the obese state was 175 (Table I). After weight loss, it decreased to 152 . Both of these means are somewhat inflated by the inclusion of one massively obese subject. The mean \%IBW for the other seven subjects was 153 before and 133 after weight loss. The mean weight loss for the eight subjects was $16 \mathrm{~kg}$.

The level of AT-LPL activity of the eight subjects before and after weight loss was compared to the relationship between AT-LPL activity and \%IBW in a group of normal control subjects (Fig. 1). The subjects making up this control line were nonreduced, nonsmoking males who had been stable at their usual weight for a minimum of several months.

Seven of eight patients showed a rise in their AT-LPL activity after weight loss. The AT-LPL activity in the obese state was $2.17 \pm 1.17$ compared with $9.33 \pm 8.93$ $\mathrm{mU} / 10^{6}$ cells after weight loss (difference: $7.16 \pm 9.20$, $P=0.03$ ). The data points of the patients studied when obese fell on or about the control regression line, developed from data of other individuals, and deviated upward off the line after restabilization at a reduced weight (Fig. 2). Four subjects were restudied 8-14 mo after their weight reduction (Table II). Three subjects had regained their lost weight with a return of AT-LPL activity to near their obese levels. One subject had maintained most of his lost weight and continued to have elevated AT-LPL activity.

The fractional rate of weight loss was greater during the initial period of the hypocaloric diet $(0.30 \pm 0.06 \%)$ than during the second period of the hypocaloric diet $(0.11 \pm 0.07 \%, P<0.01)$ in the four subjects weight stabilized halfway through the weight loss protocol (Fig. 3). In these subjects the initial period of weight loss was $41 \pm 5 \mathrm{~d}$; the second period was $44 \pm 11 \mathrm{~d}$. There was an inverse correlation between the change in ATLPL activity and the fractional rate of weight loss (Fig. 3).

Measurement of plasma lipoprotein levels (Table I) revealed a reduction in very low density lipoprotein triglyceride (VLDL-TG) from $166 \pm 90 \mathrm{mg} / \mathrm{dl}$ in the obese state to $115 \pm 56 \mathrm{mg} / \mathrm{dl}$ after weight stabilization at the reduced weight; however, this was not a statistically significant decline $(P=0.09)$. Plasma high density lipoprotein (HDL) cholesterol level increased significantly from an obese level of $30 \pm 4 \mathrm{mg} / \mathrm{dl}$ to $40 \pm 10$ $\mathrm{mg} / \mathrm{dl}$ after weight reduction (difference: $9.50 \pm 12.55$, $P=0.05)$. The change in HDL cholesterol did not correlate with the change in AT-LPL activity.

\section{DISCUSSION}

Most of the metabolic abnormalities associated with obesity have been shown to normalize with weight loss $(6-11)$ and thus are likely a consequence of the obese state, not a cause. In the present study, the high AT-LPL activity usually seen in obesity did not decrease after weight stabilization at a reduced weight but in fact became more elevated. The persistent elevation of enzyme activity for $10 \mathrm{mo}$ in the single individual who was able to maintain most of the weight loss suggests the increase in AT-LPL activity continues indefinitely, as indicated in a previous retrospective study of weight loss (17). In that study, elevation of AT-LPL activity was demonstrated in a weight reduced population studied 4-28 mo after losing weight. Furthermore, AT- 


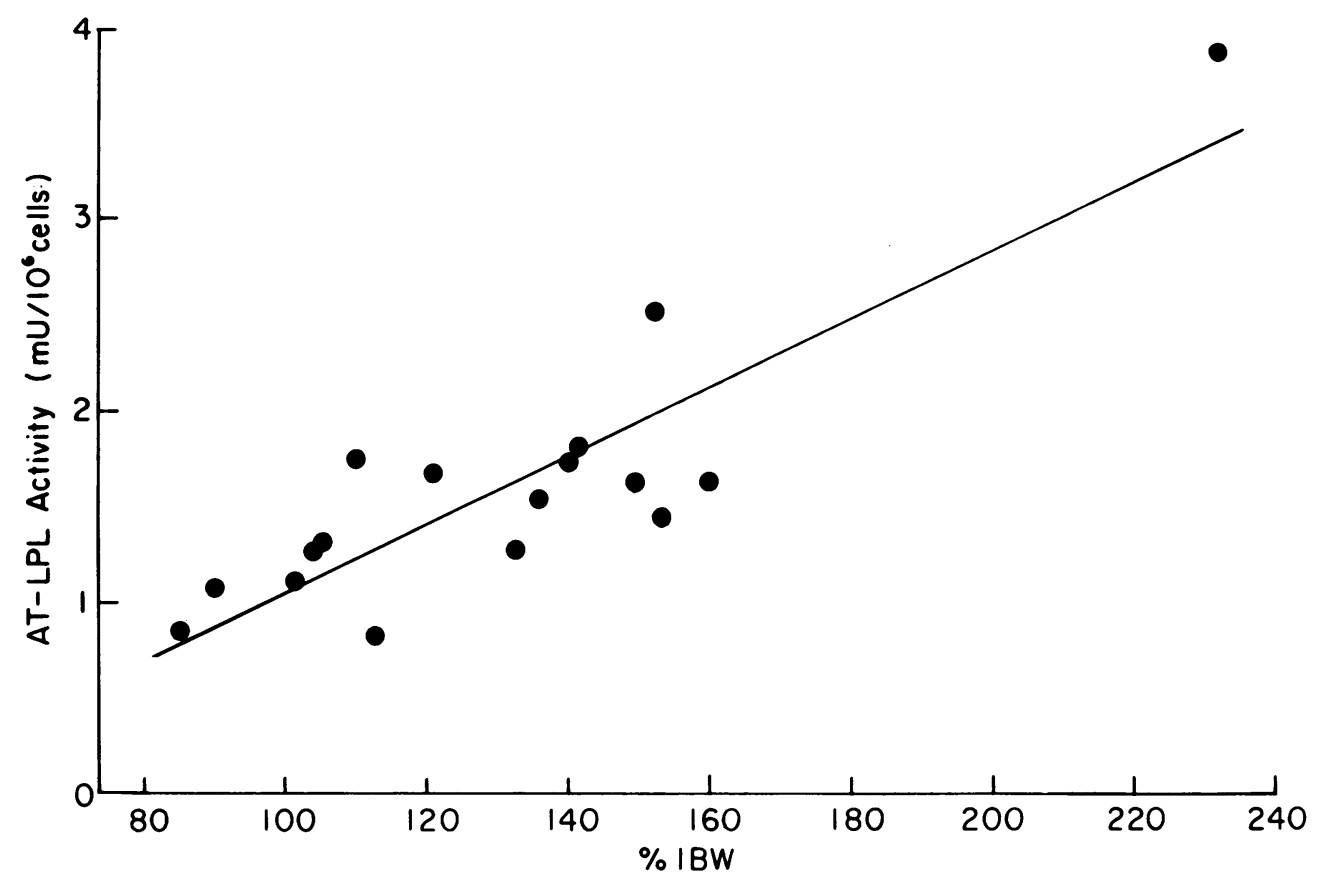

FIGURE 1 Relationship between AT-LPL activity (mU/10 $0^{6}$ cells) and \%IBW for 17 weight-stable, nonsmoking controls $(r=0.87, P<0.001)$. AT-LPL activity also correlated with fat cell size (micrograms of triglyceride per cell) in the control subjects $(r=0.85, P<0.001)$.

LPL activity returned to the lower level present before weight loss after a gain in weight to the previous obese state. The elevation of enzyme activity in the weightreduced state and the fall with regained weight indicate that the enzyme activity in adipose tissue is under feedback control.

Others (22-24) who have looked at the change in AT-LPL activity with weight loss have found a decline.

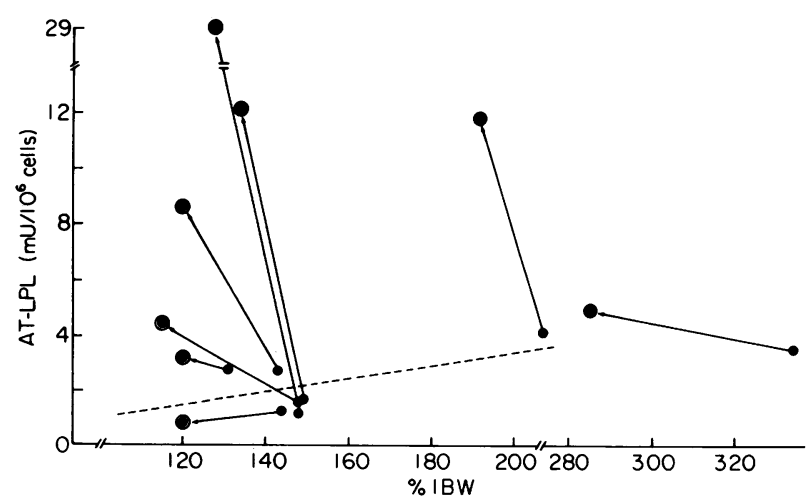

FIGURE 2 Study subjects before $(\odot)$ and after weight loss $(\odot)$ are compared to the regression line (-- ) for the 17 weightstable control subjects of Fig. 1. Significant correlations between AT-LPL activity and \% IBW $(r=0.71, P<0.05, n=7)$ and between AT-LPL activity and fat cell size $(r=0.81, P$ $<0.01, n=8$ ) were present in the obese subjects before weight loss.
In their studies, however, subjects were evaluated while still hypocaloric. In two subjects studied while on the 600-cal diet in our protocol, a fall in AT-LPL activity below that in the basal obese state was confirmed (unpublished data), indicating that the hypocaloric state during weight loss is different from the eucaloric state after weight loss.

Genetically obese rats $(\mathrm{fa} / \mathrm{fa})$ restricted in their food

TABLE II

Long-term Follow-up

\begin{tabular}{lcrccc}
\hline & Months & Weight & IBW & Fat cell size & AT-LPL \\
\hline & & $k g$ & $\%$ & $\mu g$ TG/cell & $m U / 10^{8}$ cells \\
2 Obese & \multicolumn{1}{c}{0} & 103 & 148 & 0.576 & 1.44 \\
Reduced & \multicolumn{1}{c}{3.5} & 80 & 115 & 0.573 & 4.45 \\
Obese & 15 & 103 & 148 & 0.634 & 1.25 \\
Obese & 0 & 99 & 143 & 0.770 & 2.01 \\
Reduced & 4 & 83 & 120 & 0.678 & 8.42 \\
Obese & 18 & 103 & 149 & 0.770 & 2.59 \\
7 Obese & 0 & 95 & 148 & 0.484 & 1.12 \\
Reduced & 3.5 & 84 & 130 & 0.571 & 29.03 \\
Obese & 12 & 106 & 164 & 0.732 & 2.95 \\
Obese & 0 & 252 & 333 & 0.743 & 3.49 \\
Reduced & 7 & 213 & 285 & 0.560 & 4.97 \\
Reduced & 17 & 234 & 313 & 0.720 & 5.74 \\
\hline
\end{tabular}




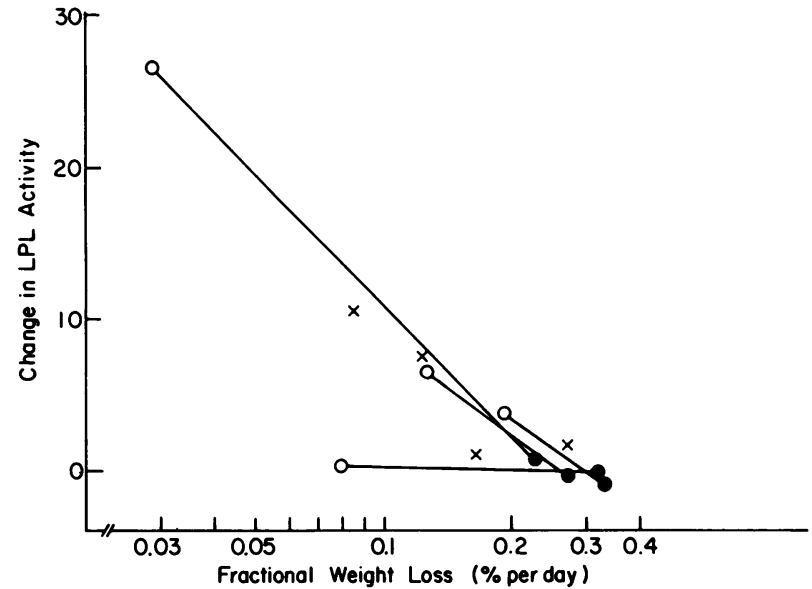

FIGURE 3 Comparison of the change in AT-LPL activity and the fractional rate of weight loss. Fractional weight loss was calculated as the change in weight divided by the initial weight times 100 , divided by the number of days on the hypocaloric diet. Four subjects remained on the hypocaloric diet throughout the study $(x)$. Four subjects were weight stabilized at the midpoint of the study to divide the periods of weight loss into an initial period of weight loss $(\Theta)$ and a second period of weight loss (O). The change in AT-LPL activity was inversely correlated with fractional weight loss ( $\times$ and $0: n=8$, $r=-0.81, P<0.01 ; \times$ and $\bigcirc: n=8, r=-0.71, P<0.05)$.

intake have been shown to have elevated AT-LPL activity and greater fat mass when compared with lean (fa/fa) littermates of equal weight (25). In fact, foodrestricted fat rats had AT-LPL activity similar to or greater than the ad libitum fed fat rats that had greater body weight and fat mass. The elevation in AT-LPL activity has been shown to be the first detectable metabolic abnormality in these genetically obese animals, occurring $2 \mathrm{wk}$ before any detectable increase in body weight, fat cell size, or insulin concentration. These authors (25) speculate that the high AT-LPL activity can, by predisposing to excess triglyceride storage in fat tissue, cause relative obesity even without hyperphagia.

Because the uptake of lipoprotein triglyceride fatty acids by human adipose tissue has been shown to be correlated with the AT-LPL activity present in that tissue (26), it is likely that the elevated AT-LPL activity seen with weight loss would predispose to increased triglyceride storage. How the increase in enzyme activity and the increase in fat cell size, adipose mass, and the impressive tendency of patients to regain lost weight are related is not known. Preferential shunting of calories away from other tissues to adipose tissue during eucaloric intake, as occurs in the fa/fa rat (25), cannot be directly evaluated in the present study. The inverse relationship between the increase in ATLPL activity and the fractional rate of weight loss in the subjects in the present study indirectly indicates that the enzyme is important in the maintenance of adipose mass. The increase in enzyme activity may account for some of the decreased rate of weight loss commonly seen with a prolonged hypocaloric diet.

To help determine the functional significance of the increase in AT-LPL activity seen in the weight-stable, reduced men in the present study, VLDL-TG and HDL cholesterol were measured before and after weight loss. It is well known that one of the primary effects of the AT-LPL enzyme is to clear circulating triglyceride from the plasma (12) and that individuals with low AT-LPL activity have elevated triglyceride levels $(27,28)$. Most subjects have lower triglyceride levels and rates of VLDL-TG synthesis after weight loss (7). In the present study VLDL-TG was lower in seven subjects and higher in one subject after weight loss. Both an increase in AT-LPL activity and a decrease in the rate of VLDLTG synthesis (7) could account for a decrease in triglyceride levels after weight loss. Subjects with comparable obesity in the study of Olefsky et al. (7) had a decrease in the rate of VLDL-TG synthesis with weight loss. However, most of those subjects also had an increase in the rate of fractional removal of plasma triglyceride, compatible with an increase in AT-LPL activity. It is probable that both effects occur; which is predominant was not determined.

Plasma HDL cholesterol levels have recently been correlated with AT-LPL activity (29), and in the present study a significant rise in the HDL cholesterol was found for the group after weight loss, even though the response was quite variable. This rise in HDL cholesterol in the stable weight-reduced state confirms a previous report (30) and may be mediated by the concomitant change in AT-LPL activity (31).

We conclude that AT-LPL activity per cell is elevated in obesity and further increases after weight loss. The increase in AT-LPL persists in a stable reduced population 4-28 mo after initial weight loss. In subjects who regained their lost weight, the AT-LPL decreased to the previous obese level. We postulate that the increase in AT-LPL activity seen after weight stabilization at a reduced weight is a counterregulatory mechanism predisposing to increased triglyceride storage in adipose tissue and is involved in the reattainment of a "set point" for weight or fat cell size.

\section{ACKNOWLEDGMENTS}

We thank Martha Kimura and Steve Hashimoto for their expert technical assistance and Sharon Kemp for her skilled secretarial assistance.

These studies were performed in the Clinical Research Center at the University of Washington Hospital. Computational assistance was provided by CLINFO computer system. This work was supported by National Institutes of Health grants AM 02456 and HL 18687. 


\section{REFERENCES}

1. Lew, E. A., and L. Garfinkel. 1979. Variations in mortality by weight among 750,000 men and women.J. Chronic Dis. 32: 563-576.

2. Stunkard, A., and M. McLaren-Hume. 1959. Results of treatment for obesity: review of the literature and report of series. Arch. Intern. Med. 103: 79-85.

3. Wing, R. R., and R. W. Jeffery. 1979. Outpatient treatments of obesity: a comparison of methodology and clinical results. Int. J. Obesity. 3: 261-279.

4. Sims, E. A. H., E. Danforth, Jr., E. S. Horton, G. A. Bray, J. A. Glennon, and L. B. Salans. Endocrine and metabolic effects of experimental obesity in man. Recent. Prog. Horm. Res. 29: 457-487.

5. Bray, G. A., and A. Campfield. 1975. Metabolic factors in the regulation of calorie stores. Metab. Clin. Exp. 24: 99-117.

6. Bagdade, J. D., E. L. Bierman, and D. Porte, Jr. 1967. The significance of basal insulin levels in the evaluation of insulin response to glucose in diabetic and nondiabetic subjects. J. Clin. Invest. 46: 1549-1557.

7. Olefsky, J., G. M. Reaven, and J. W. Farquhar. 1974. Effects of weight reduction on obesity. Studies of lipid and carbohydrate metabolism in normal and hyperlipoproteinemic subjects. J. Clin. Invest. 53: 64-76.

8. Salans, L. B., S. W. Cushman, and R. E. Weismann. 1973. Adipose cell size and number in nonobese and obese patients. J. Clin. Invest. 52: 929-941.

9. Bjorntorp, P. 1966. Studies on adipose tissue from obese patients with and without diabetes mellitus. II. Basal and insulin-stimulated glucose metabolism. Acta Med. Scand. 179: 229-234.

10. Salans, L. B., and S. W. Cushman. 1975. In Obesity in Perspective. G. Bray, editor. Department of Health, Education and Welfare Pub. No. (NIH) 75-708, Washington, D. C. 2: 245.

11. Knittle, J. L., and F. Ginsberg-Fellner. 1972. Effect of weight reduction on in vitro adipose tissue lipolysis and cellularity in obese adolescents and adults. Diabetes. 21 : 754-761.

12. Robinson, D. S. 1970. The function of plasma triglycerides in fatty acid transport. In Comprehensive Biochemistry. M. Florkin and E. H. Stotz, editors. Elsevier, Amsterdam. 18: 51 .

13. Robinson, D. S., and D. R. Wing. 1970. Regulation of adipose tissue clearing factor lipase activity. In Adipose Tissue Regulation and Metabolic Functions. B. Jeanrenaud and D. Hepp, editors. Georg Thieme Verlag KG, Stuttgart. 41-46.

14. Blanchette-Mackie, E. J., and R. O. Scow. 1971. Site of lipoprotein lipase activity in adipose tissue perfused with chylomicrons. Electron microscopic cytochemical study. J. Cell Biol. 51: 1-25.

15. Lithell, H., J. Boberg, K. Hellsing, and U. Waern. 1978. Lipoprotein-lipase activity in subcutaneous adipose tissue in healthy subjects. Variation of activity in a population of 60-year-old men. Ups. J. Med. Sci. 83: 45-52.

16. Pykalisto, O. J., P. H. Smith, and J. D. Brunzell. 1975. Determinants of human adipose tissue lipoprotein lipase: effects of diabetes and obesity on basal and diet induced activity. J. Clin. Invest. 56: 1108-1117.

17. Schwartz, R. S., and J. D. Brunzell. 1978. Increased adipose tissue lipoprotein lipase in moderately obese men after weight reduction. Lancet I: 1230-1231.

18. Goldberg, A., D. J. Sherrard, and J. D. Brunzell. 1978. Adipose tissue lipoprotein lipase in chronic hemodialysis: role in plasma triglyceride metabolism. J. Clin. Endocrinol. Metab. 47: 1173-1182.

19. Sjoström, L., P. Bjorntorp, and J. Vrana. 1971. Microscopic fat cell size measurements of frozen cut adipose tissue in comparison with automatic determinations of osmium fixed fat cells. J. Lipid Res. 12: 521-530.

20. Goldrick, R. B. 1967. Morphological changes in the adipocyte during fat deposition and mobilization. Am. J. Physiol. 212: 777-782.

21. Manual of Laboratory Operations. Lipid Research Clinics Program. 1974. Lipid and lipoprotein analysis. Department of Health, Education and Welfare (NIH) 75-628, Washington, D. C.

22. Persson, B,., B. Hood, and G. Angervall. 1970. Effects of prolonged fast on lipoprotein lipase activity eluted from human adipose tissue. Acta Med. Scand. 188: 225-229.

23. Guy-Grand, B., and B. Bigorie. 1975. Effect of fat cell size, restrictive diet and diabetes on lipoprotein lipase release by human adipose tissue. Horm. Metab. Res. 7: 471-475.

24. Taskinen, M.-R., and E. A. Nikkilä. 1979. Effects of calorie restriction on lipid metabolism in man. Changes of tissue lipoprotein lipase activities and of serum lipoproteins. Atherosclerosis. 32: 289-299.

25. Cleary, M. P., J. R. Vasselli, and M. R. C. Greenwood. 1980. Development of obesity in Zucker obese (fafa) rat in absence of hyperphagia. Am. J. Physiol. 238: E284E292.

26. Taskinen, M.-R., and E. A. Nikkilä. 1977. Lipoprotein lipase activity in adipose tissue and in post heparin plasma in human obesity. Act Med. Scand. 202: 399-408.

27. Goldberg, A. P., A. Chait, and J. D. Brunzell. 1980. Postprandial adipose tissue lipoprotein lipase activity in primary hypertriglyceridemia. Metabolism Clin. Exp. 29: 223-229.

28. Brunzell, J. D. 1979. Endocrine disorders and adipose tissue lipoprotein lipase. In Lipoprotein Metabolism and Endocrine Regulation. L. W. Hessel and H. M. J. Krans, editors. Elsevier/North Holland Biomedical Press, New York. 27-34.

29. Nikkilä, E. A., M.-R. Taskinen, and M. Kekki. 1978. Relation of plasma high density lipoprotein cholesterol to lipoprotein lipase activity in adipose and skeletal muscle of man. Atherosclerosis. 29: 497-501.

30. Avogaro, P., G. Cazzolato, B. G. Bittolo, and G. B. Quinci. 1979. Variations of plasma lipoproteins and apolipoproteins $B$ and $A$ in obese subjects fed with hypocaloric diet. Obesity/Bariatric Med. 8: 158-161.

31. Brunzell, J. D., P. Magill, S. N. Rao, N. Miller, R. J. St. Hilaire, A. Nicoll, and B. Lewis. 1979. High density lipoprotein kinetics and adipose tissue lipoprotein lipase. Circulation. 60 (Suppl. II): 70. 